\title{
Diurnal variability of upper ocean temperature and heat budget in the southern Bay of Bengal during October - November, 1998 (BOBMEX-Pilot)
}

\author{
V S N Murty, V Ramesh Babu, L V G Rao, Charuta V Prabhu and V Tilvi \\ National Institute of Oceanography, Dona Paula, Goa 403004, India.
}

\begin{abstract}
Time-series data on upper-ocean temperature, Vessel-Mounted Acoustic Doppler Current Profiler (VM-ADCP) measured currents and surface meteorological parameters have been obtained for the first time in the southern Bay of Bengal at $7^{\circ} \mathrm{N}, 10^{\circ} \mathrm{N}$, and $13^{\circ} \mathrm{N}$ locations along $87^{\circ} \mathrm{E}$ during October November, 1998 under BOBMEX-Pilot programme. These data have been analysed to examine the diurnal variability of upper oceanic heat budget and to estimate the eddy diffusivity coefficient of heat in the upper layer. Diurnal variation of near-surface temperature is typical at northern location $\left(13^{\circ} \mathrm{N}\right)$ with a range of $0.5^{\circ} \mathrm{C}$ while the diurnal range of temperature is enhanced to $0.8^{\circ} \mathrm{C}$ at the central location $\left(10^{\circ} \mathrm{N}\right)$ due to intense solar radiation $\left(1050 \mathrm{~W} / \mathrm{m}^{2}\right)$, clear skies and low wind speeds. At the southern location $\left(7^{\circ} \mathrm{N}\right)$, the diurnal variation of temperature is atypical with the minimum temperature occurring at $2000 \mathrm{hrs}$ instead of at early morning hours. In general, the diurnal curve of temperature penetrated up to 15 to $20 \mathrm{~m}$ with decreasing diurnal range with depth. The VM-ADCP measured horizontal currents in the upper ocean were predominantly easterly/northeasterly at southern location, north/northerly at central location and northwesterly at northern location, thus describing a large-scale cyclonic gyre with the northward meridional flow along $87^{\circ} \mathrm{E}$. The magnitudes of heat loss at the surface due to air-sea heat exchanges and in the upper $50 \mathrm{~m}$ layer due to vertical diffusion of heat are highest at the southern location where intense convective activity followed by overcast skies and synoptic disturbance prevailed in the lower atmosphere. This and the estimated higher value $\left(0.0235 \mathrm{~m}^{2} / \mathrm{s}\right)$ of eddy diffusivity coefficient of heat in the upper ocean (0-50 m depth) suggest that 1-D processes controlled the upper layer heat budget at the southern location. On the other hand, during the fair weather conditions, at the central and northern locations, the upper layer gained heat energy, while the sea surface lost (gained) heat energy at northern (central) location. This and lower values of eddy diffusivity coefficient of heat $(0.0045$ and $0.0150 \mathrm{~m}^{2} / \mathrm{s}$ ) and the northward intensification of horizontal currents at these locations suggest the greater role of horizontal heat advection over the 1-D processes in the upper ocean heat budget at these two locations.
\end{abstract}

\section{Introduction}

Under the earlier Monsoon Experiment programmes (MONEX-77, MONEX-79 and MONTBLEX-90) in the Bay of Bengal, time-series measurements were conducted in the northern and central Bay and the results of the data analysis were published in various scientific journals (Rao et al 1985, Rao and Rao 1986, Rao 1987, Rao et al 1991,1993, Sanilkumar et al 1994,
Murty et al 1996, Sarma et al 1997). Under the recent Bay of Bengal and Monsoon Experiment-Pilot (BOBMEX-Pilot) programme, time-series measurements of temperature, salinity and VM-ADCP currents in the upper $500 \mathrm{~m}$ were carried out at $7^{\circ} \mathrm{N}, 10^{\circ} \mathrm{N}$ and $13^{\circ} \mathrm{N}$ locations along $87^{\circ} \mathrm{E}$ in the southern Bay during 29th October - 8th November 1998. The period of timeseries measurements varied from 48 hours at the southern and central locations to 25 hours at the

Keywords. Bay of Bengal; upper ocean heat budget; BOBMEX; eddy diffusivity of heat. 
Table 1. Details of the time-series locations occupied during BOBMEX-Pilot.

\begin{tabular}{lcccc}
\hline Location & Latitude & Longitude & Period & Julian Day \\
\hline 1 & $7^{\circ} \mathrm{N}$ & $87^{\circ} \mathrm{E}$ & 0245 IST of 30.10.98 to 0135 IST of 01.11.98 & $303-304$ \\
2 & $10^{\circ} \mathrm{N}$ & $87^{\circ} \mathrm{E}$ & 0240 IST of 02.11.98 to 0255 IST of 04.11.98 & $306-308$ \\
3 & $13^{\circ} \mathrm{N}$ & $87^{\circ} \mathrm{E}$ & 0150 IST of 05.11.98 to 0340 IST of 06.11.98 & 309 \\
\hline
\end{tabular}

northern location (table 1). A detailed description of the prevailing synoptic conditions in the southern Bay of Bengal during BOBMEX-Pilot programme has been provided by Bhat et al (2000). These authors expect that the synoptic conditions that prevailed were representative of the cyclone period or persistence of active southwest monsoon in the southern Bay of Bengal. Large-scale convective activity followed by overcast skies and synoptic weather depressions associated with the Inter-Tropical Convergence Zone (ITCZ) characterise the meteorological forcing at the southern location $\left(7^{\circ} \mathrm{N}, 87^{\circ} \mathrm{E}\right)$ during 30 th - 31st October, 1998. Clear sky and shallow cumulus clouds were mainly observed from 2nd to 6th November, 1998 during the period of measurements at the central $\left(10^{\circ} \mathrm{N}, 87^{\circ} \mathrm{E}\right)$ and southern $\left(13^{\circ} \mathrm{N}, 87^{\circ} \mathrm{E}\right)$ locations. In this paper, the authors discuss the diurnal variability of the upper ocean heat budget in relation to the observed differential synoptic weather conditions over the southern Bay of Bengal during BOBMEX-Pilot period (October - November, 1998).

\section{Materials and methods}

Profiles of temperature and salinity in the upper $500 \mathrm{~m}$ were obtained using a Seabird CTD (SBE plus 9/11) at 3 hourly interval at three stationary locations $\left(7^{\circ} \mathrm{N}\right.$, $10^{\circ} \mathrm{N}$ and $13^{\circ} \mathrm{N}$ ) along $87^{\circ} \mathrm{E}$ (figure 1 ). At the southern $\left(7^{\circ} \mathrm{N}, 87^{\circ} \mathrm{E}\right)$ and the central $\left(10^{\circ} \mathrm{N}, 87^{\circ} \mathrm{E}\right)$ locations, CTD measurements were taken for 48 hours while at the northern location $\left(13^{\circ} \mathrm{N}, 87^{\circ} \mathrm{E}\right)$ these measurements were taken for 25 hours. Bucket thermometer was used to measure the sea surface temperature (SST). Surface meteorological parameters such as air temperature, relative humidity, wind speed and direction, atmospheric pressure and global solar radiation were recorded at 10 minute interval through on board Automatic Weather Station (AWS). The wind data were obtained from two similar sets of sensors located at $22.6 \mathrm{~m}$ height above the sea surface on the port and starboard sides of the vessel. The true wind speed and direction referred to True North were estimated using the ship's heading and speed at each time interval for both the sets of sensors. The correct wind data set was carefully chosen for the analysis. The atmospheric pressure recorded by AWS was compared and corrected with the simultaneously recorded aneroid barometric pressure data. Data processing details along with the data are provided in the BOBMEX-Pilot CD-ROM (Anon 2000). Finally, the 1 hour interval

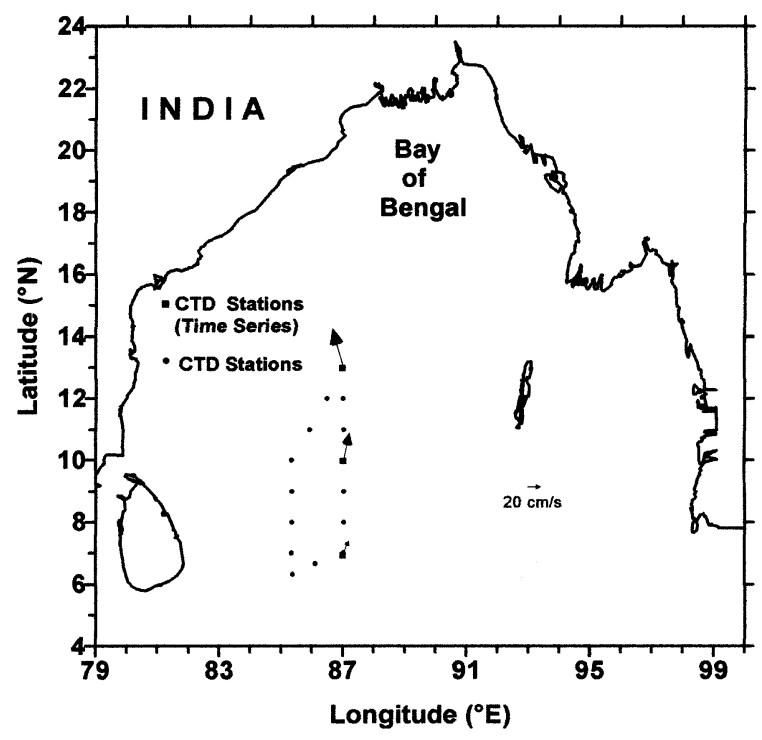

Figure 1. Study area showing the time-series locations during BOBMEX-Pilot observational period (29th October-8th November 1998). VM-ADCP measured mean currents vectors in the 30-50 m layer (at the time-series locations) are also depicted. Northward increase of the mean current speed is evident.

SST data was supplemented with the 1 hour interval AWS surface meteorological data to make a comprehensive data set to estimate the heat fluxes across the air-sea interface. Bulk aerodynamic formulae are used to estimate the net long wave radiation $\left(Q_{b}\right)$, latent heat flux $\left(Q_{e}\right)$ and sensible heat flux $\left(Q_{h}\right)$. The hourlymean incoming solar radiation, $Q_{i}$, as obtained through AWS is considered as heat input to the upper layer. The net heat flux $\left(Q_{n}\right)$ at the sea surface is estimated as a residual of the following heat balance equation (Stevenson 1982, Zavialov and Murty 1995):

$$
Q_{n}=Q_{i}-Q_{b}-Q_{h}-Q_{e} .
$$

The computational scheme for obtaining the coefficients of bulk formulae for $Q_{b}, Q_{h}$ and $Q_{e}$, and the procedure for computing each of the heat flux parameters are adopted from Sarma et al (1997).

The heat content in the upper $50 \mathrm{~m}(\mathrm{H})$ layer is estimated from the temperature profiles at the timeseries locations using the equation (Murty et al 1996):

$$
H=\rho C_{p} \int_{0}^{50} T d z
$$

where $\rho$ is the water density, $C_{p}$ is the specific heat at constant pressure and $T$ is the temperature, $z$ is the depth and $d z$ is the depth interval $(=1 \mathrm{~m})$. 


\section{Results and discussion}

\subsection{Diurnal variation of temperature and upper layer heat content}

For the present study, we have used the time series CTD data covering a day from midnight to midnight of 24 hours duration at the southern and central locations though data are available for 48 hours of duration. However, the variations in the weather and oceanic parameters during the omitted days at the southern and central locations have been discussed as when required. Figures $2(\mathrm{a}-\mathrm{c})$ show the vertical profiles of temperature in the upper $100 \mathrm{~m}$ at southern, central and northern locations plotted for the Julian days 304 (31st October), 307 (3rd November) and 309 (5th November) respectively. These profiles indicate considerable vertical and horizontal variability. At all the locations, the temperature of the mixed layer is about $28.5^{\circ} \mathrm{C}$, but at $100 \mathrm{~m}$ depth the waters are cooler $\left(19^{\circ}-21^{\circ} \mathrm{C}\right)$ at the southern location and warmer $\left(23^{\circ}-24^{\circ} \mathrm{C}\right)$ at the northern location. Vertical excursions in the thermocline are large at the southern location and minimum at the northern location. The temporal variations in temperature in the upper $100 \mathrm{~m}$ water column are minimum at the northern location when compared to that at the southern and central locations. At southern location, the surface mixed layer is deep $(70 \mathrm{~m})$ at $0355 \mathrm{hrs}$ and shoaled to $25 \mathrm{~m}$ at $0030 \mathrm{hrs}$ of the following day (figure 2a). At central location, the surface mixed layer is about $20 \mathrm{~m}$ thick and among the profiles, the minimum temperature difference is noticed at $50 \mathrm{~m}$ (figure $2 \mathrm{~b}$ ). At the northern location, surface mixed layer is homogenous up to $40 \mathrm{~m}$ and among the profiles, the minimum temperature difference can be found at $25 \mathrm{~m}$ (within the mixed layer) and at $90 \mathrm{~m}$ (within thermocline).

Thermosalinograph measured continuous near-surface $(\sim 3 \mathrm{~m}$ depth) temperature data (corrected with the bucket SST data) is used to examine the diurnal variation of near-surface temperature and its deviation over the daily mean value is presented in figures $3(\mathrm{a}-\mathrm{c})$ at the southern, central and northern locations. At southern location, diurnal range is about $0.5^{\circ} \mathrm{C}$ with a maximum positive deviation value occurring at $1300 \mathrm{hrs}$ and minimum value at $2000 \mathrm{hrs}$ (figure $3(\mathrm{a})$ ). At the central location, the diurnal range is large $\left(0.8^{\circ} \mathrm{C}\right)$ with the minimum deviation at $0200 \mathrm{hrs}$ and maximum deviation $\left(0.55^{\circ} \mathrm{C}\right)$ occurring at $1500 \mathrm{hrs}$ (figure 3(b)) due to intense insolation on this day under cloud free and low wind speed conditions. The temperature curve sharply drops to $0.1^{\circ} \mathrm{C}$ by $1600 \mathrm{hrs}$. At northern location, the temperature curve shows a range of $0.47^{\circ} \mathrm{C}$ with minimum deviation $\left(-0.25^{\circ} \mathrm{C}\right)$ around $0500 \mathrm{hrs}$ and maximum deviation $\left(0.22^{\circ} \mathrm{C}\right)$ at $1300 \mathrm{hrs}$ and after $1300 \mathrm{hrs}$ the temperature drop is very gradual till midnight hours
Temperature $\left({ }^{\circ} \mathrm{C}\right)$

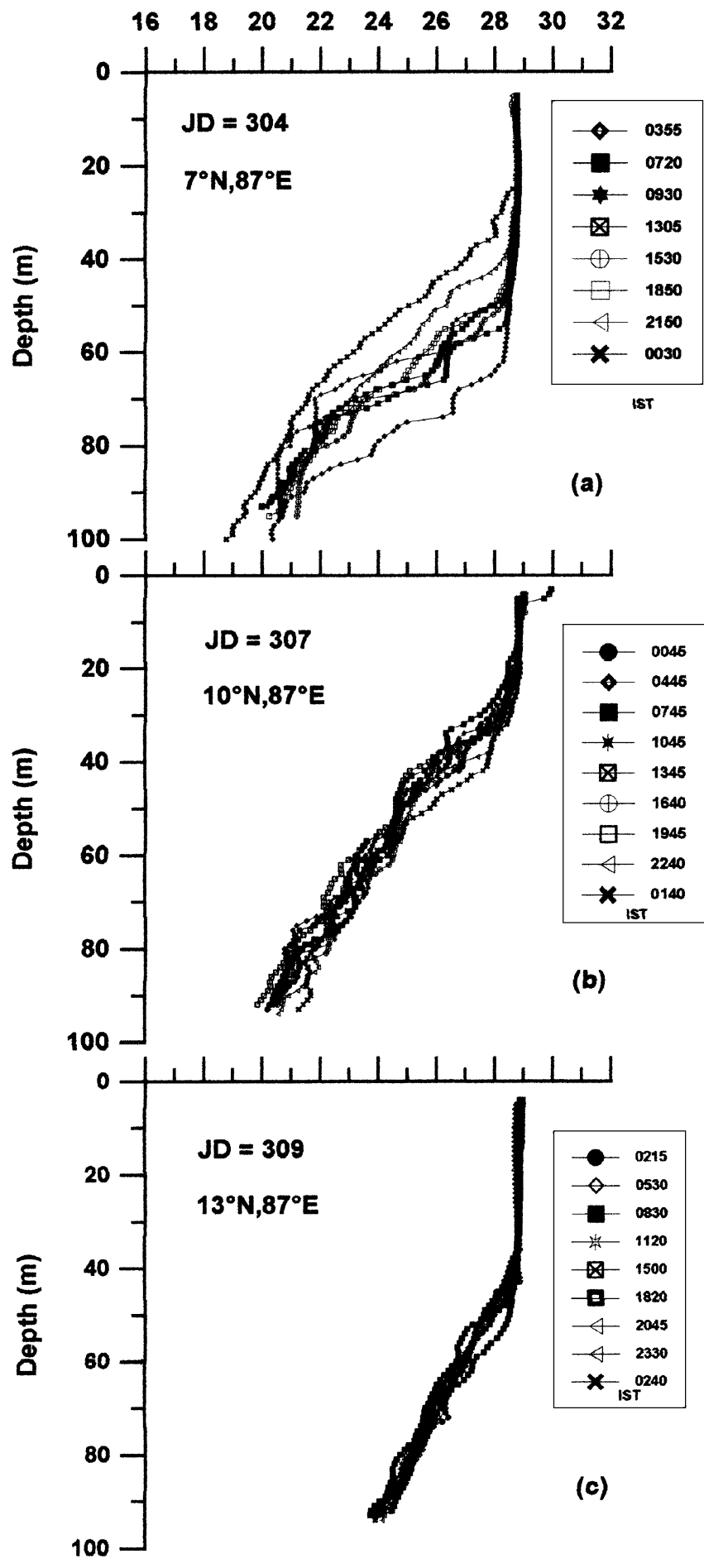

Figure 2. Profiles of temperature in the upper $100 \mathrm{~m}$ at the time-series locations: (a) $7^{\circ} \mathrm{N}, 87^{\circ} \mathrm{E}$, (b) $10^{\circ} \mathrm{N}, 87^{\circ} \mathrm{E}$ and (c) $13^{\circ} \mathrm{N}, 87^{\circ} \mathrm{E}$ for the Julian days 304 (31st October), 307 (3rd November) and 309 (5th November) respectively.

(figure 3(c)). From the above, it can be seen that the diurnal temperature curve at southern location is atypical with the occurrence of minimum temperature at night hours, when compared to that at central and northern locations. 


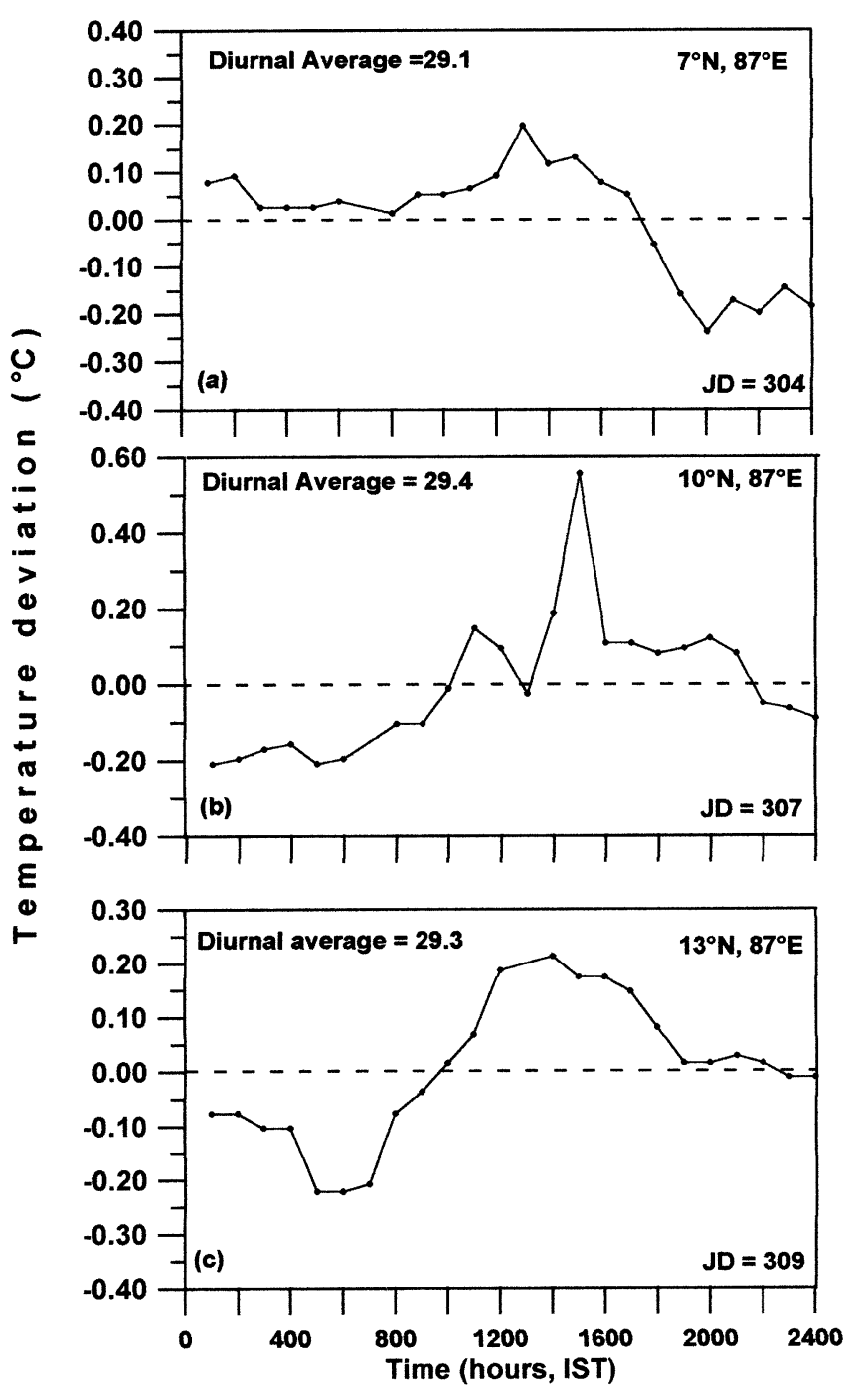

Figure 3. Diurnal variation of deviation of near-surface temperature ( $\sim 3 \mathrm{~m}$ below surface) from the daily mean value at the time-series locations: (a) $7^{\circ} \mathrm{N}, 87^{\circ} \mathrm{E}$, (b) $10^{\circ} \mathrm{N}, 87^{\circ} \mathrm{E}$ and (c) $13^{\circ} \mathrm{N}, 87^{\circ} \mathrm{E}$ for Julian days 304,307 and 309 respectively, based on thermosalinograph measurements. Please note the change in the upper limit of ordinate scales.

Utilising the CTD data, the diurnal variation of temperature at subsurface depths (below $3 \mathrm{~m}$ ) is examined as deviations over the daily mean value at three depths, viz., 5, 10, $20 \mathrm{~m}$ at all the three locations (figures 4(I)a-c, 4(II)a-c and 4(III)a-c). The diurnal temperature curves at southern location at these depths also are atypical with large minimum occurring at night hours (2000-2100 hrs). At the central and northern locations, the diurnal curves of temperature are typical with a minimum value at early hours and maximum value around noon at the depths of 5 and $10 \mathrm{~m}$. The trend of diurnal variation is reversed at $20 \mathrm{~m}$ depth at all the locations. In general, the diurnal range of temperature decreased with depth. At southern location, the diurnal range of temperature at $5 \mathrm{~m}$ is the same as that at surface (figure 4(I)a and figure 3a). The diurnal range dropped to as low as $0.1^{\circ} \mathrm{C}$ at $10 \mathrm{~m}$. At $20 \mathrm{~m}$, the trend of diurnal variation is reversed and the temperature deviation is close to zero, suggesting that the diurnal temperature curve is affected by the vertical excursions in the thermocline (figure 2(a)). At central station, the daily mean temperature decreases from $5 \mathrm{~m}$ to $20 \mathrm{~m}$ (figure $4(\mathrm{IIb})$ ). The diurnal range of temperature deviation is exceptionally large i.e., $0.9^{\circ} \mathrm{C}$ at $5 \mathrm{~m}$ (figure $4(\mathrm{IIb})$ ) and shows a typical diurnal cycle as that at near-surface (figure 3(b)). This indicates the penetration of intense solar radiation up to this depth under fair weather conditions with low wind speeds. At northern location, the diurnal range of temperature is considerably small $\left(0.26^{\circ} \mathrm{C}\right)$ at both $5 \mathrm{~m}$ and $10 \mathrm{~m}$ and further decreased to $0.2^{\circ} \mathrm{C}$ at $20 \mathrm{~m}$ (figure $4(\mathrm{IIIC})$ ).

The upper layer heat content $(\mathrm{H})$ is computed up to $50 \mathrm{~m}$ depth wherein the diurnal temperature curve penetrates close to $20 \mathrm{~m}$ depth. The diurnal variation of deviation of $\mathrm{H}$ from the daily mean value at the three locations (figures $5(\mathrm{a}-\mathrm{c})$ ) is large during night and is negative at southern location and positive at the other two stations. This indicates that the trend of heat storage over the diurnal cycle is heat loss from the upper layer at southern location and heat gain to this layer at central and northern locations and the heat gain is relatively more at central location (figure $5(\mathrm{~b})$ ). The heat loss from the upper layer at southern location results from the upward shift of the thermocline in association with the intense convective activity followed by overcast skies and synoptic weather disturbance. The lesser $\left(0.5^{\circ} \mathrm{C}\right)$ diurnal range of temperature at the southern location is due to the prevailing synoptic weather conditions, as against the larger diurnal range of $0.8^{\circ} \mathrm{C}$ at the central location where fair weather conditions with intense solar radiation prevailed.

\subsection{Diurnal variation of surface meteorological para- meters and surface heat budget components}

The diurnal variability of the meteorological forcing at the sea surface at the three locations is presented in figures $6(a-j)$. For this purpose, we used the AWS recorded meteorological parameters. The wind speed and direction over the diurnal period at the three locations exhibited wide variations both in the direction and speed (figures $6(\mathrm{a}-\mathrm{b})$ ). At southern location, on 31st October, the wind speeds were low $(<5 \mathrm{~m} / \mathrm{s})$ and changed from west to northwest/north from $0000 \mathrm{hrs}$ to $1200 \mathrm{hrs}$ (figure $6(\mathrm{a}))$. Moderate $(>5 \mathrm{~m} / \mathrm{s}$ ) southwesterly winds prevailed from $1200 \mathrm{hrs}$ to 2400 hrs. On the previous day, 30th October, 1998, the winds were from southwest with relatively strong speeds $(10 \mathrm{~m} / \mathrm{s})$ in the early morning and weaker wind speeds $(2.5 \mathrm{~m} / \mathrm{s})$ around noon. At central location, on 3rd November, winds were variable (southerly/northwesterly) with speeds between 2 and $9 \mathrm{~m} / \mathrm{s}$ during the first half of the day. The winds became weak $(<4 \mathrm{~m} / \mathrm{s})$ southwesterlies during the second half of the day. As 

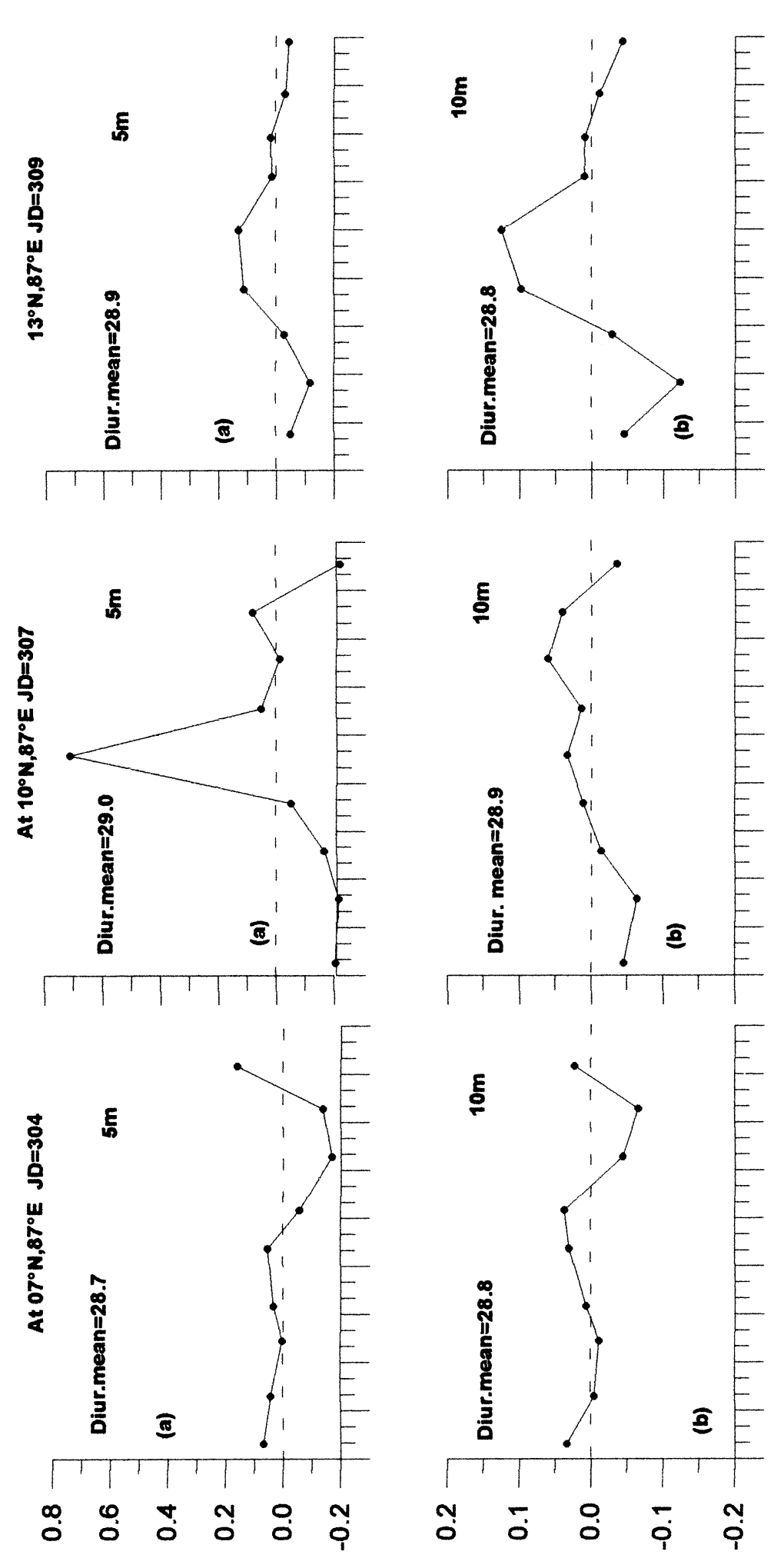

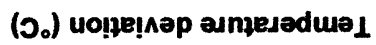

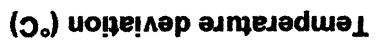

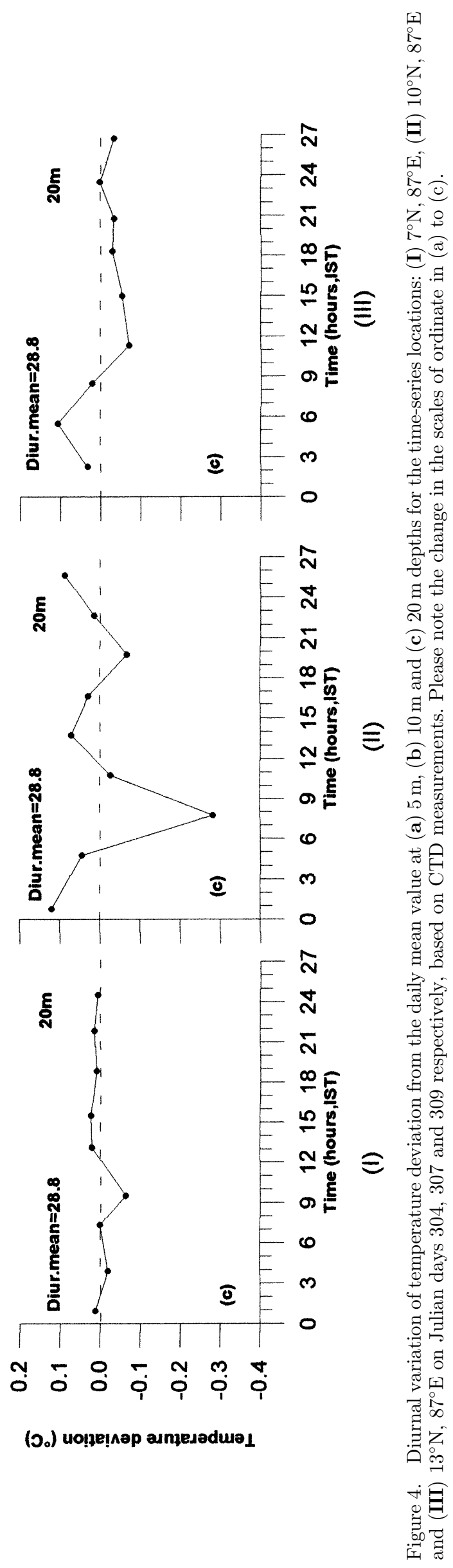




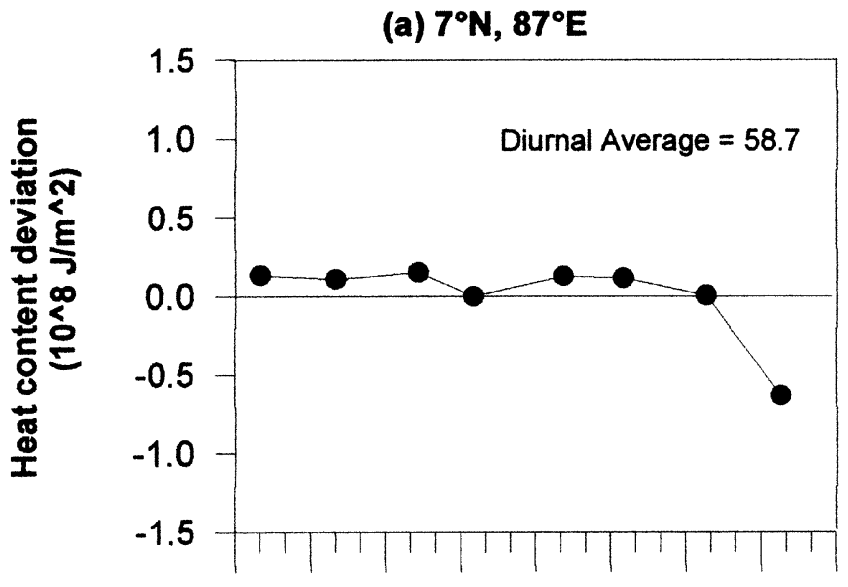

(b) $10^{\circ} \mathrm{N}, 87^{\circ} \mathrm{E}$

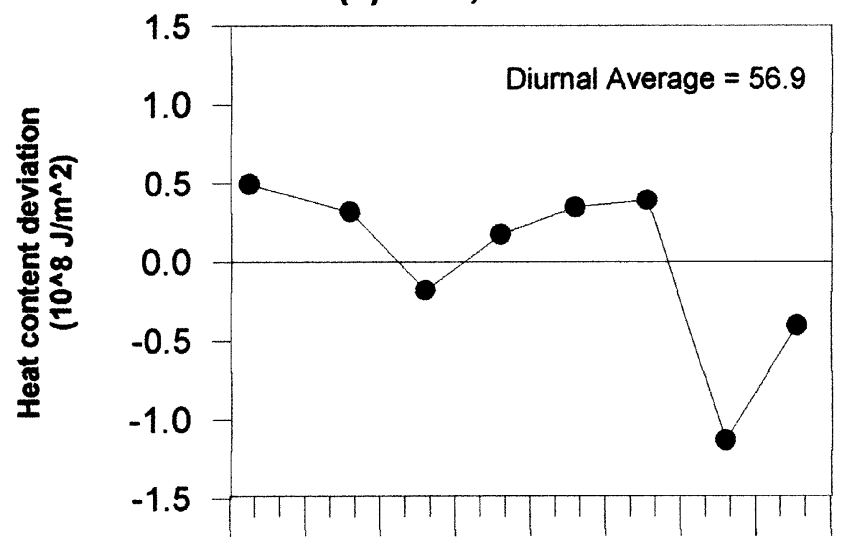

(c) $13^{\circ} \mathrm{N}, 87^{\circ} \mathrm{E}$

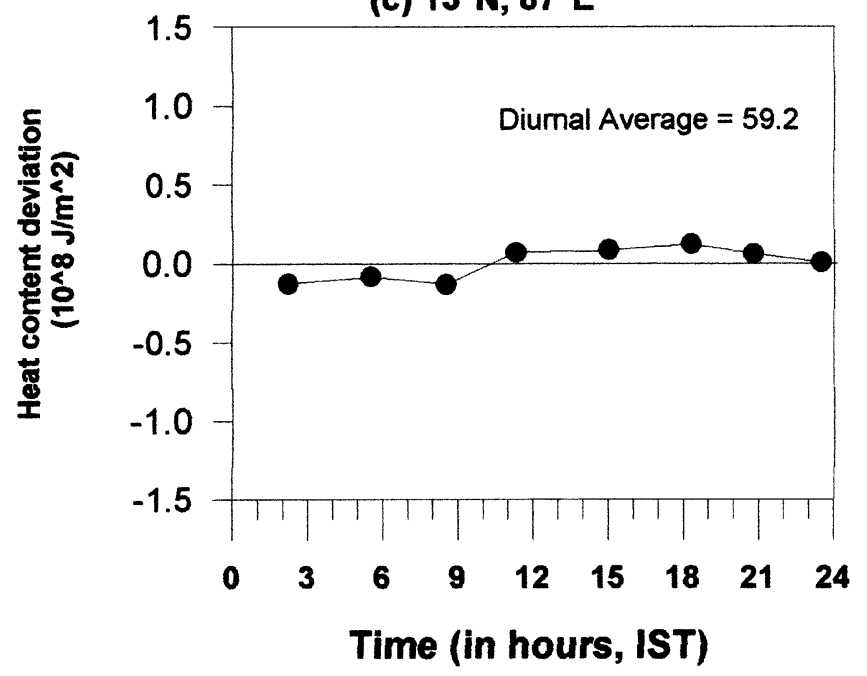

Figure 5. Diurnal variation of upper ocean $(0-50 \mathrm{~m})$ heat content deviation from its daily mean value at the time-series locations: (a) $7^{\circ} \mathrm{N}, 87^{\circ} \mathrm{E}$, (b) $10^{\circ} \mathrm{N}, 87^{\circ} \mathrm{E}$ and (c) $13^{\circ} \mathrm{N}, 87^{\circ} \mathrm{E}$ for the Julian days 304, 307 and 309 respectively.

noticed above, these weak winds help enhancing the diurnal range of temperature at this location with higher SSTs around noon. On the previous day, i.e., on 2nd November, the weather parameters indicate prevalence of fair weather conditions. At northern location, on 5th November, distinctive east/southeast winds with larger magnitudes $(>6 \mathrm{~m} / \mathrm{s})$ occurred throughout the day.

The atmospheric pressure at the sea surface showed a typical diurnal variation at all the locations (figure 6(c)) with two maxima (at 0900 and $2100 \mathrm{hrs}$ ) and two minima (0300 and $1400 \mathrm{hrs}$ ). However, typically lower pressures occurred at the central and northern stations between 1200 and $2400 \mathrm{hrs}$ depicting the influence of warmer SSTs under fair weather conditions. Air temperature exhibited wide variations at southern and central locations; a drastic decrease of $4^{\circ} \mathrm{C}$ at afternoon hours at southern location and a significant increase of $6^{\circ} \mathrm{C}$ from 0700 to $1000 \mathrm{hrs}$ at central location (figure $6(\mathrm{~d})$ ). On the previous day (30th October) also, the air temperature at southern location showed a drastic decrease by $4^{\circ} \mathrm{C}$ from noon to evening hours. This decrease in air temperature is in association with the change of northerly wind to southwesterly winds followed by decrease in SST and increase of R.H. by $10 \%$ (not shown here), indicating the northward passage of synoptic disturbance (cloud bands). At northern location, diurnal variation of air temperature is comparatively less. Associated with the significant changes in air temperature, the relative humidity exhibited wide variation; lower R.H. (50-70\%) at the southern location and higher R.H. (80-90\%) at the northern location (figure 6(e)). At the southern location, the drastic decrease of SST and air temperature followed by $20 \%$ increase in R.H. (figure $3(\mathrm{a})$ and figure 6(e)) may be related to the downdraft associated with the synoptic disturbance. Similarly, at the central location, the increase of SST and air temperature followed by a decrease in R.H. by about $15 \%$ from $0000 \mathrm{hrs}$ to $1200 \mathrm{hrs}$ could be related to the intense solar radiation due to fair weather conditions and clear skies.

The diurnal variation of global solar radiation reaching the sea surface at the three locations (figure $6(\mathrm{f})$ ) shows a day-maximum at noon at southern and northern locations; the maximum is only $400 \mathrm{~W} / \mathrm{m}^{2}$ at southern location while it is large $\left(1000 \mathrm{~W} / \mathrm{m}^{2}\right)$ at northern location. The overall low magnitudes of solar radiation at southern location reflect the significant influence of synoptic weather system and the associated overcast skies. It is to be noted that at the same location the magnitude of maximum radiation is large $\left(1000 \mathrm{~W} / \mathrm{m}^{2}\right)$ on the previous day, i.e., 30th October (not shown).

The computed effective back radiation $\left(Q_{b}\right)$ and the sensible heat flux $\left(Q_{h}\right)$ curves (figures $6(\mathrm{~g}-\mathrm{h})$ ) exhibited similar diurnal patterns. These variations correspond largely on the prevailing weather events of clear skies and intense convection. At southern location, the higher magnitudes of $Q_{b}$ and $Q_{s}$ during 1200-1700 hrs are associated with the downdraft event (lower air temperature and higher relative humidity) and the resulting large sea-air temperature 

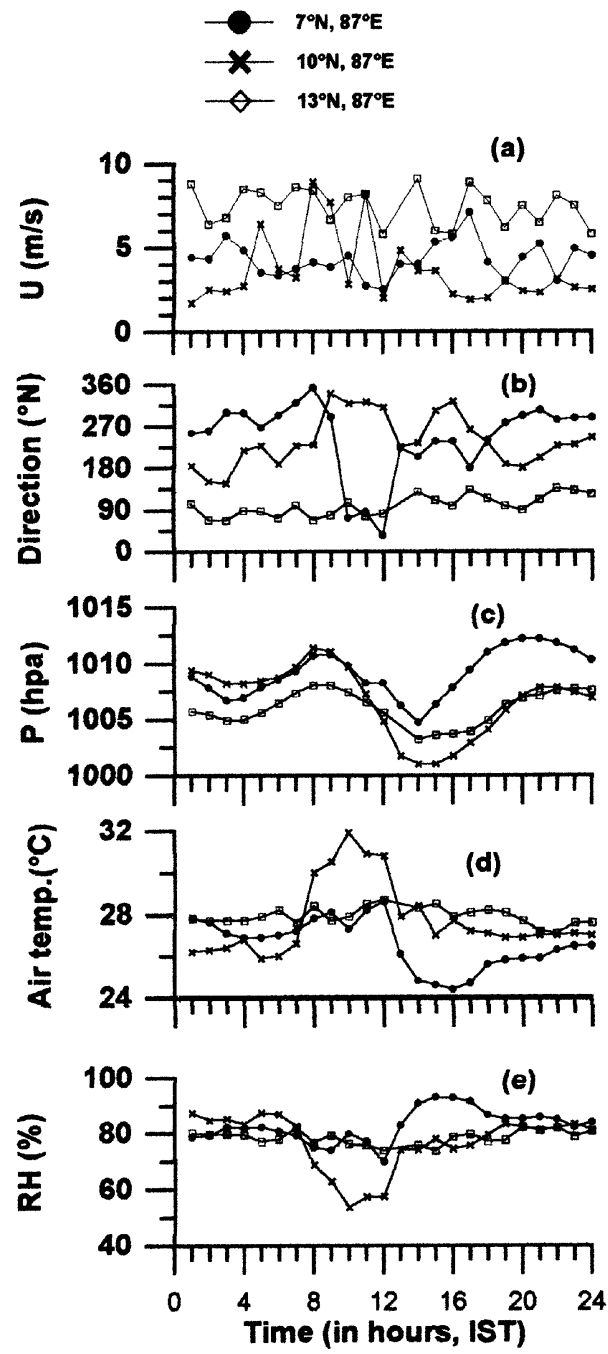
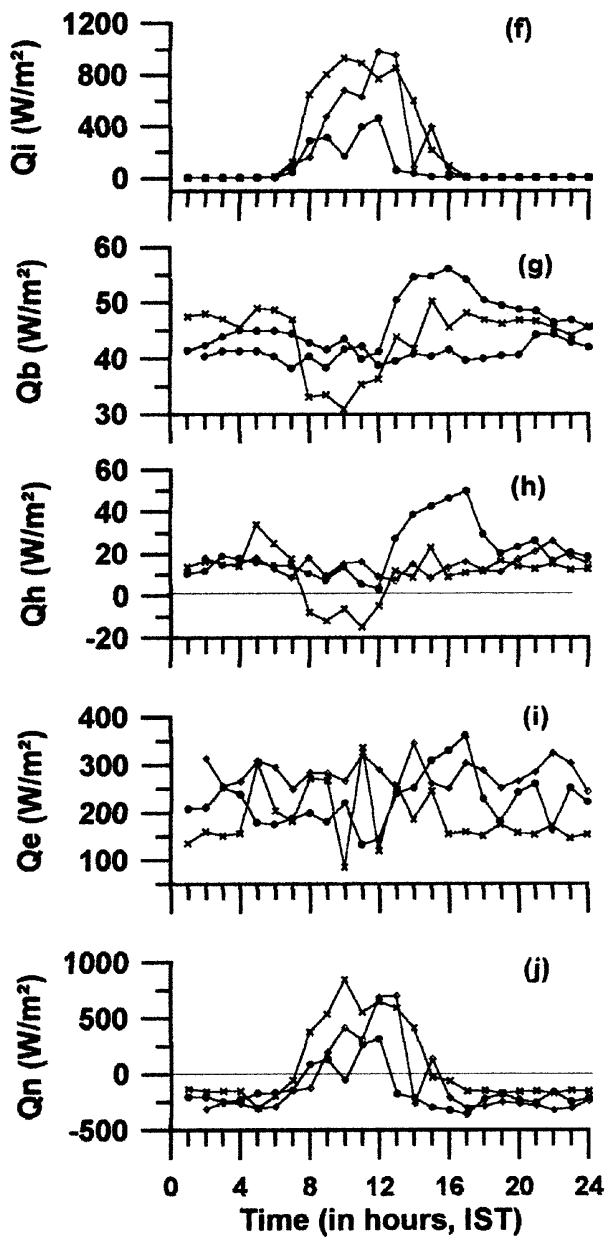

Figure 6. Diurnal variation of various surface meteorological parameters and surface heat budget components at the time-series locations: (a) $7^{\circ} \mathrm{N}, 87^{\circ} \mathrm{E}$, (b) $10^{\circ} \mathrm{N}, 87^{\circ} \mathrm{E}$ and (c) $13^{\circ} \mathrm{N}, 87^{\circ} \mathrm{E}$ for the Julian days 304,307 and 309 respectively.

difference $\left(2.5^{\circ} \mathrm{C}\right)$. Similarly, at central location, the lowest values of $Q_{b}$ and negative $Q_{h}$ during 0800$1200 \mathrm{hrs}$ correspond to the intense radiation event (warmer air temperature and lower relative humidity). At northern location, both $Q_{b}$ and $Q_{s}$ varied around $40 \mathrm{~W} / \mathrm{m}^{2}$ and $10 \mathrm{~W} / \mathrm{m}^{2}$ respectively. The latent heat flux $\left(Q_{e}\right)$ is the most important component of the surface heat budget of the tropical ocean and compensates the effect of sea surface heating due to solar radiation. The magnitudes of $Q_{e}$ are between 100 and $350 \mathrm{~W} / \mathrm{m}^{2}$ (figure $6(\mathrm{i})$ ). The latent heat flux increased rapidly from $125 \mathrm{~W} / \mathrm{m}^{2}$ to $350 \mathrm{~W} / \mathrm{m}^{2}$ during the period of downdraft at southern location and reached a peak minimum $\left(80 \mathrm{~W} / \mathrm{m}^{2}\right)$ at the time of $(1000 \mathrm{hrs})$ intense radiation at central location. It is, in general, high (above $200 \mathrm{~W} / \mathrm{m}^{2}$ ) at northern location where higher wind speeds occurred.

The pattern of net heat flux $\left(Q_{n}\right)$ which is estimated as the residual of the surface heat budget is similar to the solar radiation. The net heat flux is positive during 0700-1500 hrs at the three locations showing that the sea surface gained heat during this part of the day (figure $6(\mathrm{j})$ ). Over the diurnal cycle, the sea surface loses heat energy to a tune of $144 \mathrm{~W} / \mathrm{m}^{2}$ at southern location and nearly half of this amount at northern location (table 2). However, at central location, the sea surface gained heat energy (table 2), mainly due to intense solar radiation under relatively low cloudiness and wind speeds, contributing to higher daily mean SST at $10^{\circ} \mathrm{N}$ (table 2).

The large net heat loss at the sea surface and the northward passage of synoptic disturbance (cloud band) from $3^{\circ} \mathrm{N}$ during 30 th -31 st October 1998 at southern location have led to the shoaling mixed layer depth (MLD) and isotherms $\left(28^{\circ}, 27^{\circ}, 26^{\circ}\right.$ and $\left.20^{\circ} \mathrm{C}\right)$ in the thermocline (figure $7(\mathrm{a})$ ). At central location, deepening of MLD and the isotherms by the end of the day (3rd November, 1998) is evident in figure 7(b). At northern location, the diurnal variation of MLD and the depth of chosen isotherms is minimum (figure $7(\mathrm{c})$ ) and vertical oscillations in the thermocline are nearly absent. 
Table 2. Diurnal averages of $S S T$, wind speed (U), relative humidity (R.H.), heat input through solar radiation ( $\left.Q_{i}\right)$, heat loss components due to sensible heat flux $\left(Q_{h}\right)$, latent heat flux $\left(Q_{e}\right)$, effective back radiation $\left(Q_{b}\right)$ and net surface heat flux $\left(Q_{n}\right)$ at the time-series locations. Positive (negative) value of $Q_{n}$ indicates heat gain (loss) at sea surface.

\begin{tabular}{|c|c|c|c|c|c|c|c|c|}
\hline Location/Julian day & $\begin{array}{l}\mathrm{SST} \\
\left({ }^{\circ} \mathrm{C}\right)\end{array}$ & $\begin{array}{c}U \\
(\mathrm{~m} / \mathrm{s})\end{array}$ & $\underset{(\%)}{\text { R.H. }}$ & $\begin{array}{c}Q_{i} \\
\left(\mathrm{~W} / \mathrm{m}^{2}\right)\end{array}$ & $\begin{array}{c}Q_{h} \\
\left(\mathrm{~W} / \mathrm{m}^{2}\right)\end{array}$ & $\begin{array}{c}Q_{e} \\
\left(\mathrm{~W} / \mathrm{m}^{2}\right)\end{array}$ & $\begin{array}{c}Q_{b} \\
\left(\mathrm{~W} / \mathrm{m}^{2}\right)\end{array}$ & $\begin{array}{c}Q_{n} \\
\left(\mathrm{~W} / \mathrm{m}^{2}\right)\end{array}$ \\
\hline $07^{\circ} \mathrm{N}, 87^{\circ} \mathrm{E} / 304$ & 29.1 & 4.1 & 83 & 79 & -28 & -206 & -48 & -144 \\
\hline $10^{\circ} \mathrm{N}, 87^{\circ} \mathrm{E} / 307$ & 29.4 & 3.5 & 77 & 260 & -10 & -134 & -44 & 72 \\
\hline $13^{\circ} \mathrm{N}, 87^{\circ} \mathrm{E} / 309$ & 29.3 & 7.2 & 78 & 206 & -15 & -228 & -41 & -78 \\
\hline
\end{tabular}
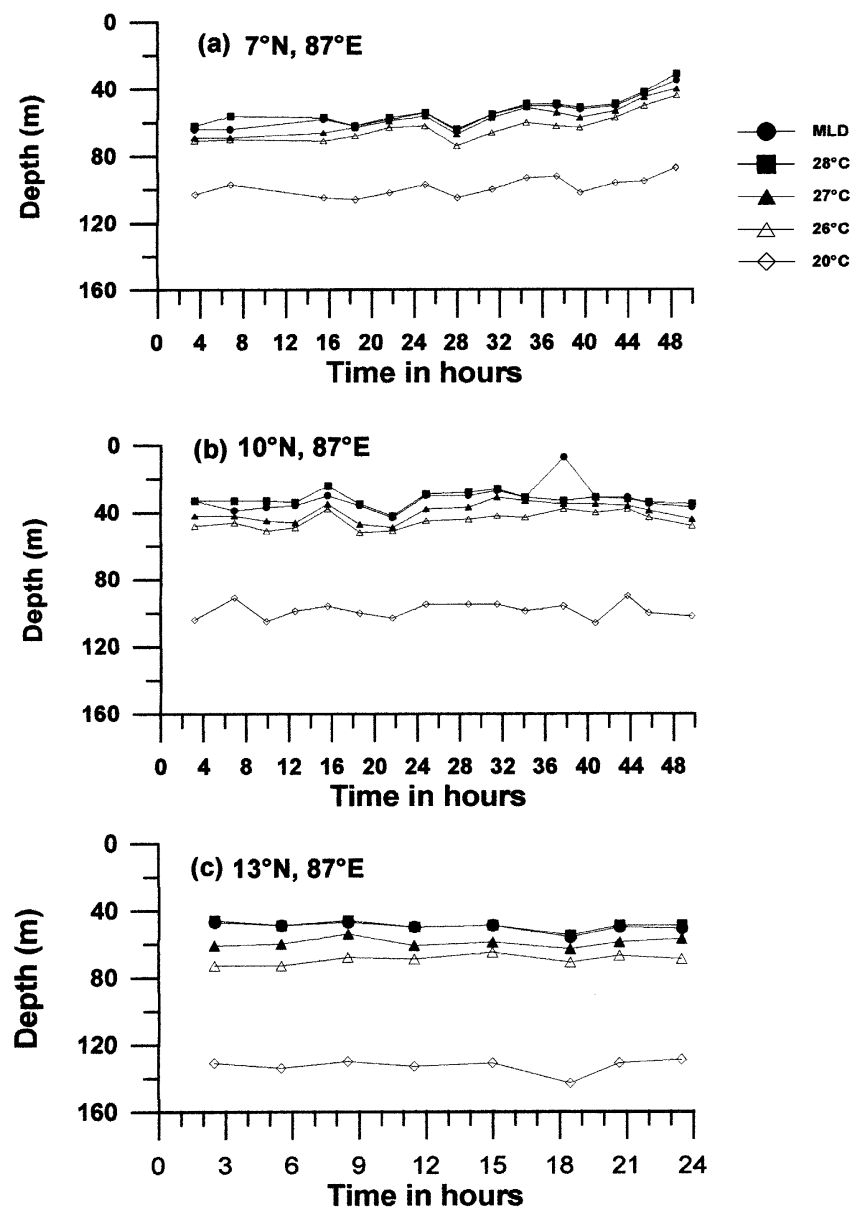

Figure 7. Diurnal variation of mixed layer depth and depths of selected isotherms $\left(28^{\circ}, 27^{\circ}, 26^{\circ}\right.$ and $\left.20^{\circ} \mathrm{C}\right)$ at the time-series locations: (a) $7^{\circ} \mathrm{N}, 87^{\circ} \mathrm{E}$, (b) $10^{\circ} \mathrm{N}, 87^{\circ} \mathrm{E}$ and (c) $13^{\circ} \mathrm{N}, 87^{\circ} \mathrm{E}$ for the Julian days 303-304, 306-308 and 309 respectively.

\subsection{Diurnal variation of VM-ADCP measured currents in the upper layer}

The VM-ADCP $(150 \mathrm{kHz}, \mathrm{RD}$ Instruments, USA) measured currents at $31 \mathrm{~m}$ and $51 \mathrm{~m}$ at the three locations are shown in figures 8 and 9 respectively. The current vectors represent the 10 minute averaged velocities, considered only when the ship's speed was below 2 knots. This explains the gaps between the current vectors and is more evident at the northern location where the observed winds were strong and the vessel drifted northwestward with speeds exceeding 2 knots during the time-series measurements. At southern and central locations, the current vectors are shown for the 2-day period of time-series observations (figures $8(\mathrm{a}-\mathrm{b}), 9(\mathrm{a}-\mathrm{b}))$. The direction of flow at $31 \mathrm{~m}$ and $51 \mathrm{~m}$ depths is almost similar at all the three locations. At southern location, the eastward current is predominant on the first day (00-24 hrs; 30th October, Julian day $=303$ ) and changed to northeastward on the 2nd day (24-48 hours; 31st October, Julian day $=304$ in figures $8(\mathrm{a}), 9(\mathrm{a}))$. This change in the current direction is in agreement with the change of winds to southwesterly under the influence of the northward passage of the synoptic disturbance (as discussed above). At central location, there appears a change in the flow from the first day (2nd November, Julian day $=306,00-24$ hours) to the second day (3rd November, Julian Day $=307,24-48$ hours). On the first day, the currents at $31 \mathrm{~m}$ and $51 \mathrm{~m}$ depths are directed north-north-east and northwestward. On the second day, the flow is changed between north and northeast (figures 8(b), 9(b)). The current vectors at northern location show strong flow with a predominant northwestward current at $31 \mathrm{~m}$ and $51 \mathrm{~m}$ depths (figures 8(c), 9(c)). The diurnal and tidal variations in the measured currents on the Julian days 304, 307 and 309 at southern, central and northern locations respectively are nearly absent. The mean current in the layer 31-51 $\mathrm{m}$ on each day at the locations is shown in table 3 . At the southern and central locations, the mean current in the layer intensified from the 1st day to the 2nd day. The mean current in the layer also intensifies from $21 \mathrm{~cm} / \mathrm{s}$ in the south to $71 \mathrm{~cm} / \mathrm{s}$ in the north (table 3). This strong current speed at the northern location agrees well with the gesotrophic velocity computed between $12^{\circ} \mathrm{N}$ and $13^{\circ} \mathrm{N}$ from the hydrographic data (Rameshbabu et al 2000). The mean current vectors on the Julian days 304, 306 and 307 are depicted in figure 1 . The northward flow of mean currents in the 31-51 m layer (depicted in figure 1 and shown in table 3) is consistent with the cyclonic circulation with a meridional flow towards north along $87^{\circ} \mathrm{E}$ as derived from the thermohaline fields (Rameshbabu et al 2000).

\subsection{Upper ocean heat budget}

The rate of change of heat storage in the oceanic upper layer is obtained as the difference between the surface heat flux into the layer and the rate of loss of 


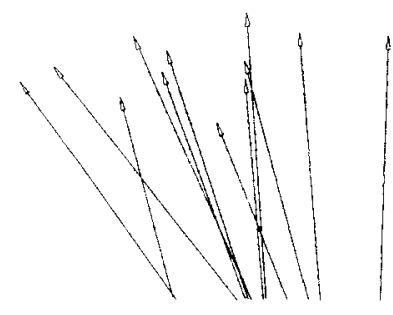

\section{Currents at $31 \mathrm{~m}$ depth}

\section{$25 \mathrm{~cm} / \mathrm{s}$}

(c) $13^{\circ} \mathrm{N}, 8^{\circ} \mathrm{E}$

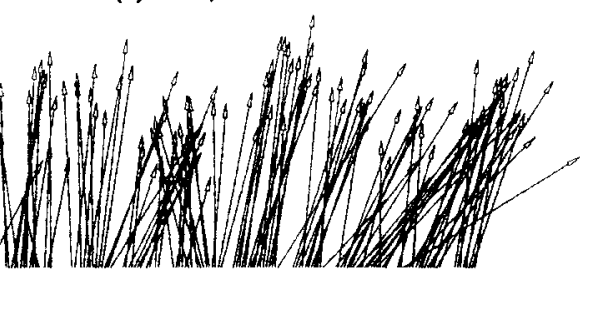

(b) $10^{\circ} \mathrm{N}, 87^{\circ} \mathrm{E}$

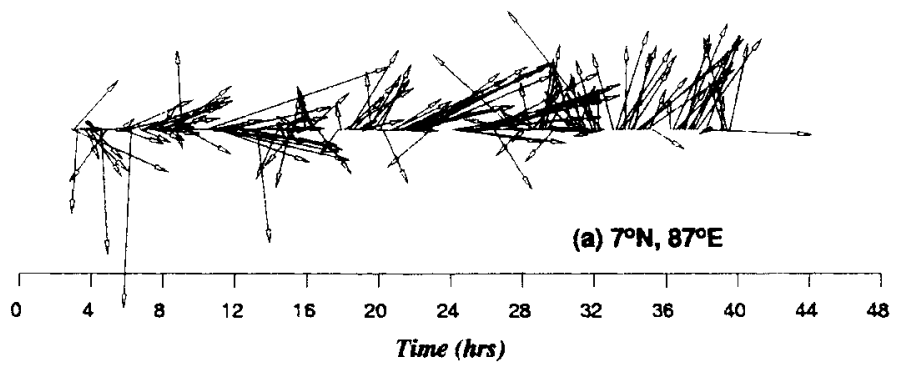

Figure 8. Temporal variation of VM-ADCP measured currents vectors at $31 \mathrm{~m}$ depth at the time-series locations: (a) $7^{\circ} \mathrm{N}, 87^{\circ} \mathrm{E}$, (b) $10^{\circ} \mathrm{N}, 87^{\circ} \mathrm{E}$ and $(\mathbf{c}) 13^{\circ} \mathrm{N}, 87^{\circ} \mathrm{E}$ for the Julian days $303-304,306-307$ and 309 respectively.

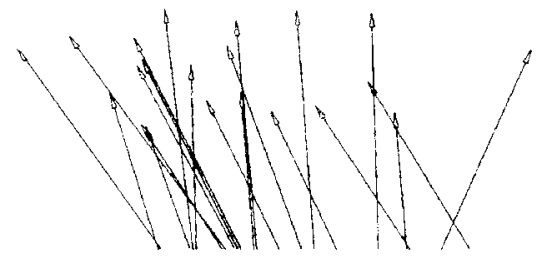

\section{Currents at $51 \mathrm{~m}$ depth}

\section{$\overrightarrow{25 \mathrm{~cm} / \mathrm{s}}$}

(c) $13^{\circ} \mathrm{N}, 8^{\circ} \mathrm{E}$

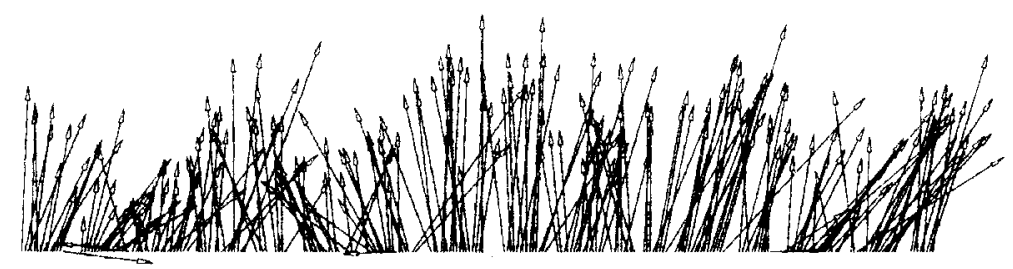

(b) $10^{\circ} \mathrm{N}, 87^{\circ} \mathrm{E}$

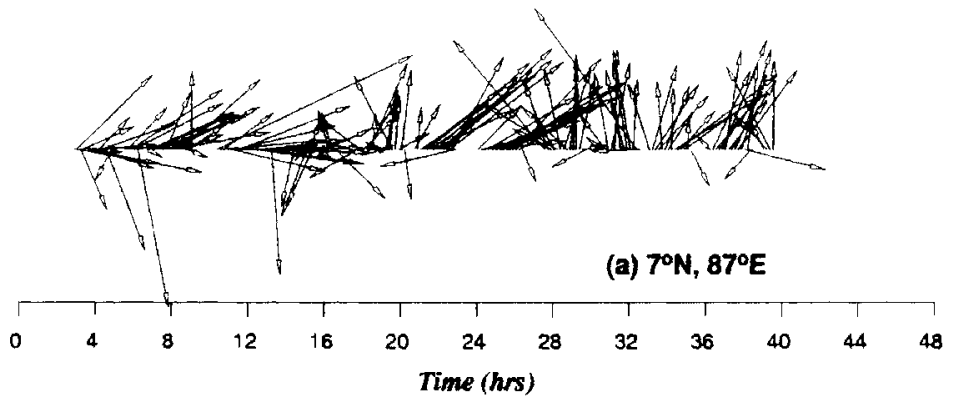

Figure 9. Same as in figure 8 , but at $51 \mathrm{~m}$ depth. 
Table 3. Diurnal averages of currents in the layer 31-51 $\mathrm{m}$ at the three time-series locations during BOBMEX-Pilot.

\begin{tabular}{lcccc}
\hline Location/Julian day & $\begin{array}{c}U \text { Zonal } \\
\text { comp. }(\mathrm{cm} / \mathrm{s})\end{array}$ & $\begin{array}{c}V \text { Meridional } \\
\text { comp. }(\mathrm{cm} / \mathrm{s})\end{array}$ & $\begin{array}{c}\text { Vectoral current } \\
\text { speed }(\mathrm{cm} / \mathrm{s})\end{array}$ & $\begin{array}{c}\text { Vectoral direction } \\
\text { of current }\end{array}$ \\
\hline $07^{\circ} \mathrm{N}, 87^{\circ} \mathrm{E} / 303$ & 14.42 & 6.27 & 16.0 & $67^{\circ}$ \\
304 & 9.19 & 18.86 & 21.0 & $26^{\circ}$ \\
\hline $10^{\circ} \mathrm{N}, 87^{\circ} \mathrm{E} / 306$ & 1.21 & 29.39 & 29.4 & $2^{\circ}$ \\
307 & 11.17 & 52.18 & 53.3 & $12^{\circ}$ \\
\hline $13^{\circ} \mathrm{N}, 87^{\circ} \mathrm{E} / 309$ & -19.30 & 68.45 & 71.0 & $344^{\circ}$ \\
\hline
\end{tabular}

heat across the bottom surface of this layer (Zavialov and Murty 1995, Delnore 1972). At the time-series locations, the upper ocean heat budget is studied considering the 1-D upper layer heat balance equation of Zavialov and Murty (1995) wherein the horizontal advection of heat is not considered. An examination of the time-series temperature profiles at each location (figures 2(a-c)) suggests that the lower boundary of the upper layer can be chosen at $50 \mathrm{~m}$ depth where minimum temperature difference is evident (with slight exception of two profiles at southern location). Further, the diurnal variability of temperature is very much confined to the upper 15-20 m layer, well within the chosen $50 \mathrm{~m}$ water column. The net heat flux at the sea surface at the three locations is given in table 2 . The rate of net heat gain in the upper $50 \mathrm{~m}$ water column over the diurnal cycle $\left(\Delta H=H_{24}-H_{00}\right)$ is estimated as the difference of heat content at $0000 \mathrm{hrs}$ from that at $2400 \mathrm{hrs}$ (Zavialov and Murty 1995).

The net heat gain in the oceanic upper layer may be written as:

$$
\Delta H=\left(Q_{n}-Q_{b o t t}\right) \Gamma
$$

where $Q_{b o t t}$ is the heat flux at the lower boundary (50 $\mathrm{m}$ depth) of the upper layer and $\Gamma=24$ hours (=86400s). The heat storage in the oceanic upper layer over the diurnal cycle $\left(Q_{t}\right)$ can be obtained from $\left(Q_{t}=\Delta H / \Gamma\right)$.

The heat flux across the lower boundary $\left(Q_{b o t t}\right)$ of the upper layer can be estimated from the equation (Zavialov and Murty 1995):

$$
Q_{b o t t}=-K_{h} \cdot \rho \cdot C_{p}(\mathrm{~d} T / \mathrm{d} z)
$$

where $K_{h}$ is the depth-averaged eddy diffusivity coefficient of heat, $\rho$ is the water density and $C_{p}$ is the specific heat at constant pressure and $d T / d z=$ temperature gradient of mean temperatures at surface and $50 \mathrm{~m}$ depth. The negative sign on the R.H.S. indicates that the $Q_{b o t t}$ is downward (from the layer).

Firstly, the value of $Q_{b o t t}$ is estimated from the values of $Q_{t}$ and $Q_{n}$ (table 4 ). Then the values of $Q_{b o t t}$ are substituted in (4) along with $\mathrm{d} T / \mathrm{d} z$ values (table 4) to estimate the depth averaged $K_{h}$ (table 4). The variation of $K_{h}$ from south to north is more closely related to the daily mean $Q_{i}$ values (table 2 ) rather than the daily mean wind speed (Hoeber 1972); the large value of $K_{h}$ is associated with lower value of $Q_{i}$ and vice versa (table 2 and table 4 ). The order of magnitudes of $K_{h}$ are in agreement with that reported by Zavialov and Murty (1995) for the upper layers of the equatorial Arabian Sea.

While the upper layer loses heat at southern location, it gains heat at the central and northern locations (values of $Q_{t}$ in table 4 ). It is more interesting to note that the upper layer loses heat across both the upper and lower boundaries at southern location, where intense convection and passage of cloud bands characterise the synoptic weather and the thermocline shoals up (figure $7(\mathrm{a})$ ). This emphasises the response of the upper ocean to the passage of large cloud band followed by intense convection and overcast skies. The computed eddy diffusivity coefficient of heat is extremely large $\left(0.0235 \mathrm{~m}^{2} / \mathrm{s}\right)$ at the southern location (table 4), suggesting that the upper ocean heat budget at this location $\left(7^{\circ} \mathrm{N}, 87^{\circ} \mathrm{E}\right)$ is controlled by $1-\mathrm{D}$ processes under the given synoptic weather conditions. On the contrary, at central and northern locations, the upper ocean gained heat mainly across the lower boundary, as the net surface heat flux is small (positive at the central location and negative at northern location). This upper ocean gain can be realised as the manifestation of thermocline deepening (evident from the profiles of temperature in figures $2(\mathrm{a}-\mathrm{c})$ and depths of $20^{\circ} \mathrm{C}$ isotherm in figures $\left.7(\mathrm{a}-\mathrm{c})\right)$

Table 4. Diurnal averages of oceanic upper layer heat budget parameters at the three time-series locations during BOBMEXPilot. $\left[Q_{n}=\right.$ net heat flux at sea surface (upper boundary of the layer), $Q_{t}=$ rate of heat storage in the upper layer, $Q_{b o t t}=$ heat flux across the lower boundary (at $50 \mathrm{~m}$ depth) of the layer, $d T / d z=$ mean temperature gradient of the layer (0-50 $\mathrm{m}$ ) and $K_{h}=$ the depth-averaged eddy diffusivity coefficient of heat. Positive (negative) values of $Q_{n}$ and $Q_{t}$ denote heat gain (loss) in

\begin{tabular}{|c|c|c|c|c|c|}
\hline Location/Julian day & $Q_{n}\left(\mathrm{~W} / \mathrm{m}^{2}\right)$ & $Q_{t}\left(\mathrm{~W} / \mathrm{m}^{2}\right)$ & $Q_{b o t t}\left(\mathrm{~W} / \mathrm{m}^{2}\right)$ & $d T / d z\left({ }^{\circ} \mathrm{C} / \mathrm{m}\right)$ & $K_{h}\left(\mathrm{~m}^{2} / \mathrm{s}\right)$ \\
\hline $07^{\circ} \mathrm{N}, 87^{\circ} \mathrm{E} / 304$ & -144 & -2092 & 1948 & -0.0202 & 0.0235 \\
\hline $10^{\circ} \mathrm{N}, 87^{\circ} \mathrm{E} / 307$ & 72 & 910 & -839 & -0.0463 & 0.0045 \\
\hline $13^{\circ} \mathrm{N}, 87^{\circ} \mathrm{E} / 309$ & -78 & 1250 & -1328 & -0.0215 & 0.0151 \\
\hline
\end{tabular}
(from) the layer. Positive (negative) value of $Q_{\text {bott }}$ indicates heat loss (gain) from (into) the layer.] 
which in turn takes place due to mass convergence in the upper layer. The northward intensification of upper layer mean currents (figure 1 and table 3) supports the thermocline deepening. At these locations, the prevailing synoptic weather was fair with almost clear skies and sea surface gains heat at central location and sea surface loses heat at northern location. Further, the computed diffusivity coefficient of heat shows extremely lower value $\left(0.0045 \mathrm{~m}^{2} / \mathrm{s}\right)$ at southern location and relatively higher value $\left(0.0150 \mathrm{~m}^{2} / \mathrm{s}\right)$ at northern location. These smaller values of $K_{h}$ (compared to that at southern location), higher mean currents and heat gain in the upper layer suggest that the horizontal advective processes dominate over the 1-D processes in the upper layer heat budget, when synoptic weather is fair. It appears that the air-sea coupling is of complex nature during fair weather conditions when compared to that during intense convective activity followed by synoptic disturbances and overcast skies.

\section{Conclusions}

Upper ocean time-series data from three locations $\left(7^{\circ} \mathrm{N}, 10^{\circ} \mathrm{N}\right.$ and $13^{\circ} \mathrm{N}$ along $\left.87^{\circ} \mathrm{E}\right)$ in the southern Bay of Bengal have been analysed. The diurnal variation of temperature varied between $0.5^{\circ} \mathrm{C}$ and $0.8^{\circ} \mathrm{C}$ and the diurnal temperature curve penetrated up to $15-$ $20 \mathrm{~m}$ depth. The incoming solar radiation reduced significantly at southern location $\left(7^{\circ} \mathrm{N}\right)$ under the influence of synoptic weather system and the associated overcast skies. The downdrafts associated with the weather depression enhanced the air-sea heat fluxes at the southern location. The study area experienced net surface heat loss both at southern and northern $\left(13^{\circ} \mathrm{N}\right)$ locations and net heat gain at central location $\left(10^{\circ} \mathrm{N}\right)$. The upper ocean lost heat energy at southern location and gained heat at central and northern locations. The estimated eddy diffusivity coefficient of heat is large $\left(0.0235 \mathrm{~m}^{2} / \mathrm{s}\right)$ at $7^{\circ} \mathrm{N}$ and low $\left(0.0045 \mathrm{~m}^{2} / \mathrm{s}\right)$ at $10^{\circ} \mathrm{N}$. The upper layer heat budget suggests that the air-sea coupling at southern location is relatively simple through 1-D processes, during intense convective activity associated with the passage of cloud band followed by synoptic weather disturbance and overcast skies. On the other hand, the air-sea coupling is of a complex nature with the horizontal advective processes dominating over the 1D processes during the fair weather with clear skies, as at central and northern locations.

\section{Acknowledgements}

The authors are thankful to the Director, NIO for his encouragement and to DST, Govt. of India, New Delhi for the financial support under ICRP. We also appre- ciate DOD for allowing necessary ship (ORV Sagar Kanya) time on board for this Pilot experiment. The authors are also thankful to the anonymous reviewer for valuable suggestions on the manuscript. This is NIO contribution No. 3569.

\section{References}

Anon 2000 BOBMEX-Pilot CD-ROM; National Institute of Oceanography Goa

Bhat G S, Ameenulla S, Venkataramana M and Sengupta K 2000 Atmospheric boundary layer characteristics during BOBMEX-Pilot experiment; Proc. Indian Acad. Sci. (Earth Planet. Sci.), (this issue)

Delnore V E 1972 Diurnal variation of temperature and energy budget for the oceanic mixed layer during BOBMEX; $J$. Phys. Oceanogr. 2 239-247

Hoeber H 1972 Eddy thermal conductivity in the upper $12 \mathrm{~m}$ of the tropical Atlantic; J. Phys. Oceanogr. 2 303-304

Murty V S N, Sarma Y V B and Rao D P 1996 Variability of the oceanic boundary layer characteristics in the head of the Bay of Bengal during MONTBLEX-90; Proc. Indian Acad. Sci. (Earth Planet. Sci.) 105 41-61

Rameshbabu V, Murty V S N, Rao L V G, Prabhu C V and Tilvi V 2000 Thermohaline structure and circulation in the upper layers of the southern Bay of Bengal during BOBMEX-Pilot (October - November 1998); Proc. Indian Acad. Sci. (Earth Planet. Sc.) (this issue)

Rao R R, Ramam K V S, Rao D S and Joseph M X 1985 Surface heat budget estimates at selected areas of north Indian Ocean during MONEX-77; Mausam 36 21-32

Rao D S and Rao R R 1986 A case study of the genesis of a monsoon low and the thermal structure of the upper north Bay of Bengal during MONEX-79; Mahasagar 19 1-9

Rao R R 1987 On the thermal response of the upper central Arabian Sea to the summer monsoonal forcing during MONSOON-77; Mausam 38 293-302

Rao R R and Kumar K V S 1991 Evolution of salinity fields in the upper layers of the east central Arabian Sea and northern Bay of Bengal during summer monsoon experiments; Proc. Indian Acad. Sci. (Earth Planet. Sci.) 100 69-78

Rao R R, Mathew B and Hareesh Kumar P V 1993 A summary of results on thermocline variability in the upper layers of the east central Arabian Sea and Bay of Bengal during summer monsoon experiment; Deep-Sea Res. I 40 1647-1672

Sanilkumar K V, Mohankumar N, Joseph M X and Rao R R 1994 Genesis of meteorological disturbances and thermocline variability of the upper layers in the head of the Bay of Bengal during Monsoon Trough Boundary Layer Experiment (MONTBLEX-90); Deep-Sea Res. 41 1569-1581

Sarma Y V B, Seetaramayya P, Murty V S N and Rao D P 1997 Influence of the monsoon trough on air-sea interaction in the head of the Bay of Bengal during the southwest monsoon of 1990 (Monsoon Trough Boundary Layer Experiment-90); Boundary-layer Meteor. 82 517-526

Sarma Y V B, Murty V S N and Rao D P 1997 Themodynamics of the oceanic and atmospheric boundary layers over head of the Bay of Bengal during the southwest monsoon of 1990. NIO Technical Report No. NIO/TR-3/97, pp. 35

Stevenson J W 1982 Computation of heat and momentum fluxes at the sea surface during the Hawaii to Tahiti Shuttle Experiment; Tech. Rep. JIMAR No. 82-0044, University of Hawaii Press, Hawaii, Honolulu, pp. 42

Zavialov P O and Murty V S N 1995 Estimation of eddy diffusivity coefficient of heat in the upper layers of equatorial Arabian Sea; Indian J. Mar. Sci. 24 177-185 